\title{
PENINGKATAN PROFESIONALISME GURU DALAM MENGAJAR MELALUI SUPERVISI KUNJUNGAN KELAS DI SDN MARGOREJO III/405 SURABAYA TAHUN PELAJARAN 2018/2019
}

\author{
Susilowati \\ SDN Margorejo III/405 Surabaya \\ e-mail: susyseno61@gmail.com
}

\begin{abstract}
Improving Teachers' Professionalism in Teaching through Class Supervision in Margorejo III/405 of Surabaya Elementary School of 2018/2019 Academic YearThe professional attitude of each teacher will show the true quality of the teacher. These competencies will be realized in the form of mastery of knowledge, skills and professional attitude in carrying out the function as a teacher. The purpose of this study is to improve teacher professionalism through supervision of classroom visit supervision. The research method used in this study is school action research (PTS). This study consists of two cycles, each cycle consists of four activities, namely planning, implementation, observation, reflection. Data collection techniques in this study are observation. Data analysis techniques in this study were using descriptive quantitative. The results of school action research showed teacher professionalism increased from cycle to cycle, in the first cycle the average value of teacher's pedagogic competence was 71.09. Whereas in the second cycle the average value of the teacher's professionalism was 77.6. Indicators of the achievement of school action research the average value of the teacher's ability to teach above 75 exceed the target set by the researcher.
\end{abstract}

Keywords: Professionalism, Supervision, Class Visits

\begin{abstract}
Abstrak
Peningkatan Profesionalisme Guru dalam Mengajar Melalui Supervisi Kunjungan Kelas di SDN Margorejo III Surabaya Tahun Pelajaran 2018/2019. Sikap profesional yang dimiliki oleh setiap guru akan menunjukkan kualitas guru yang sebenarnya. Kompetensi tersebut akan terwujud dalam bentuk penguasaan pengetahuan, keterampilan maupun sikap profesional dalam menjalankan fungsi sebagai guru. Tujuan penelitian ini adalah untuk meningkatkan profesionalisme guru melalui supervisi kunjungan kelas. Metode penelitian yang digunakan dalam penelitian ini adalah penelitian tindakan sekolah (PTS). Penelitian ini terdiri dari dua siklus, setiap siklus terdiri dari empat kegiatan, yaitu perencanaan, pelaksanaan, pengamatan, refleksi. Teknik pengumpulan data pada penelitian ini adalah observasi. Teknik analisis data pada penelitian ini adalah menggunakan kuantitatif deskriptif. Hasil penelitian tindakan sekolah menunjukkan profesionalisme guru meningkat dari siklus ke siklus, pada siklus I nilai rata-rata kompetensi pedagogik guru adalah 71,09. Sedangkan pada siklus ke II nilai rata-rata profesionalisme guru adalah 77,6. Indikator ketercapaian penelitian tindakan sekolah nilai rata-rata kemampan guru dalam mengajar diatas 75 melebihi target yang ditentukan peneliti.
\end{abstract}

Kata Kunci: Profesionalisme, Supervisi, Kunjungan Kelas 


\section{PENDAHULUAN}

Tujuan pendidikan nasional yang berfungsi mengembangkan kemampuan dan membentuk watak serta peradaban bangsa yang bermartabat dalam rangka mencerdaskan kehidupan bangsa, bertujuan untuk berkembangnya potensi peserta didik agar menjadi manusia yang beriman dan bertaqwa kepada Tuhan Yang Maha Esa, berakhlak mulia, sehat, berilmu, cakap, kreatif, mandiri, dan menjadi warga negara yang demokratis serta bertanggung jawab.

Guru memegang peran utama dalam pembangunan pendidikan, khususnya yang diselenggarakan secara formal di sekolah. Guru juga sangat menentukan keberhasilan peserta didik terutama dalam kaitannya dalam proses belajar mengajar. Guru merupakan komponen yang paling berpengaruh terhadap terciptanya proses dan hasil pendidikan yang berkualitas. Oleh karena itu, upaya perbaikan apapun yang dilakukan untuk meningkatkan kualitas pendidikan tidak akan memberikan yang signifikan tanpa didukung oleh guru yang profesional dan berkualitas. Dengan kata lain, perbaikan kualitas pendidikan harus berpangkal dari guru dan berujung pada guru pula (E. Mulyasa, 2008:5).

Hasil belajar di sekolah tidak hanya dipengaruhi oleh peserta didik yang giat belajar dan dapat memahami pelajaran di sekolah, namun peran seorang guru juga sangat penting dalam menentukan hasil belajar peserta didik tersebut dan juga kondisi lingkungan sekolahnya yang mendukung. Lingkungan sekolah yang nyaman dan bersih dapat mendukung perkembangan peserta didik secara optimal, anak-anak menjadi lebih sehat dan dapat berpikir secara jernih, sehingga dapat menjadi anak- anak yang cerdas dan kelak menjadi sumber daya manusia yang berkualitas. Lingkungan sekolah merupakan salah satu tempat yang paling umum digunakan sebagai media pembelajaran dalam proses belajar mengajar di Indonesia.

Guru merupakan salah satu komponen pendidikan yang pada hakekatnya merupakan perangkat dalam sistem pendidikan. Guru memegang peranan penting yang amat penting dan merupakan kunci keberhasilan pelaksanaan pendidikan khususnya di sekolah. Dalam hal ini pengadaan dan pembinaan guru pertu diperhatikan. Penyelenggaraan pendidikan perlu ditangani secara efektif dan profesional.

Hal ini tentu saja menyangkut masalah pengadaan dan pembinaan guru. Sebab tanpa ditangani secara efektif dan proporsional akan banyak masalah yang timbul dalam penyelenggaraan pendidikan. Pembinaan dan penilaian guru setara tenaga pendidikan lainnya pada semua jenjang dan jenis pendidikan di dalam dan luar sekolah perlu ditingkatkan dan diselenggarakan secara terpadu untuk meningkatkan hasil tenaga pendidikan lainnya yang bermutu dan dalam jumlah memadai serta perlu ditingkatkan pengembangan karier dan kesejahteraan tenaga pendidikan lainnya.

Bagi tenaga pendidikan atau guru tentu saja mempunyai hambatan yang tidak sama antara guru yang mengajar di daerah pinggir kota dengan guru yang mengajar di tengah kota. Hambatanhambatan itu tentu saja akan membawa dampak kemasalah yang lain terutama dalam peningkatan prestasi, baik prestasi 
guru atau menciptakan siswa berprestasi. Menurut Abidin yang dikutip oleh Ametembun dalam bukunya supervisi pendidikan, penuntun bagi para penilik, pengawas, kepala sekolah, dan guruguru, bahwa hambatan-hambatan dalam pendidikan itu ialah masih banyak kesadaran tugas guru dalam melaksanakan kewajiban masih tipis.

Dengan adanya kendala tersebut maka sangatlah wajar jika pemerintah menetapkan sistem pengawasan melekat terhadap guru-guru di sekolah. Di dalam pengawasan tersebut termasuk perilaku petugas supervisi kunjungan kelas terhadap profesionalisme guru, dimana masalah profesionalisme guru ini tentu saja sangat mempengaruhi terhadap peningkatan prestasi dalam pendidikan dan pengajaran. Sejalan dengan usaha peningkatan profesional guru ini, maka Menteri Pendidikan dan Kebudayaan melalui kebijakan umumnya menetapkan tentang peningkatan mutu guru sebagai usaha meningkatkan mutu pendidikan dan mutu pengajaran yang tertera dalam Keputusan Mendikbud Nomor 0416/U/1987. Kemudian bahwa profesionalisme dan prestasi guru itu akan dapat dilihat dalam Daftar Penilaian Pelaksanaan Pekerjaan (DP3).

Sikap profesional atau kompetensi diartikan sebagai pengetahuan, keterampilan dan nilai-nilai dasar yang direfleksikan dalam kebiasaan berpikir dan bertindak. Arti lain dan sikap profesional adalah spesifikasi dari pengetahuan, keterampilan, dan etika yang dimiiiki seseonang serta penerapannya di dalam pekerjaan, sesuai dengan standar kinerja yang dibutuhkan oleh lapangan. Dengan demikian, sikap profesional yang dimiliki oleh setiap guru akan menunjukkan kualitas guru yang sebenarnya. Kompetensi tersebut akan terwujud dalam bentuk penguasaan pengetahuan, keterampilan maupun sikap profesional dalam menjalankan fungsi sebagai guru.

Berdasarkan pengertian tersebut, sikap profesional Guru adalah suatu pernyataan tentang kriteria yang dipersyaratkan, ditetapkan dan disepakati bersama dalam bentuk penguasaan pengetahuan, keterampilan dan sikap bagi seorang tenaga kependidikan sehingga layak disebut kompeten. sikap profesional guru atau kompetensi yang dimaksud meliputi kompetensi pedagogik, kompetensi kepribadian, kompetensi sosial, dan kompetensi profesionaf yang diperofeh melalui pendidikan profesi.

Dalam peningkatan profesionalisme guru ini sebagai usaha peningkatan mutu pendidikan dan pengajaran maka perilaku petugas supervisi kunjungan kelas bagi guru dalam melaksanakan tugas-tugasnya mengajar merupakan faktor utama dalam pengawasan. Oleh karenanya sistem pengawasan tersebut ditetapkan oleh Mendikbud agar pelaksanaan tugas-tugas guru berjalan dengan efektif Kemudian mengenai tugas guru tersebut yang berkaitan dengan tugas dan tanggung jawab guru, tertera dalam kode etik guru (pedoman dasar seorang guru).

Peningkatan profesionalisme guru bisa dilakukan dengan kegiatan supervisi. Salah satuk Teknik supervisi yany bisa diterapkan adalah supervisi kunjungan kelas. Kunjungan kelas adalah kunjungan yang dilakukan oleh supervisor terhadap 
kelas-kelas tertentu pada sekolah-sekolah yang telah direncanakan diprogram untuk mendapatkan gambaran atau data tentang pelaksanaan proses pembelajaran di dalam kelas (Depdikbud, 2000 : 19). Ada beberapa yang perlu perhatikan dalam melakukan kunjungan kelas antara lain :

1. Kunjungan dapat dilakukan dengan memberi tahu atau tidak memberi tahu, tergantung pada tujuan dan masalah yang ingin diketahui.

2. Kunjungan dapat dilakukan atas permintaan sekolah atau guru yang bertugas dalam sekolah tersebut.

3. Supervisor hendaknya memiliki pedoman tentang hal-hal yang akan dilakukan dalam kunjungan kelas yang dimaksud, baik instrumen atau catatan lainnya.

4. Tujuan dan sasaran kunjungan harus jelas bagi supervisor yang melakukan kunjungan kelas tersebut.

Langkah-langkah yang ditempuh dalam pelaksanaan kegiatan supervisi kujungan kelas mencakup beberapa hal, antara lain: persiapan, pelaksanaan, penilaian dan tindak lanjut.

1. Persiapan

Kegiatan persiapan yang perlu dilakukan dalam rangka melakukan supervisi tunjungan kelas adalah :

a. Penyusunan program dan organisasi supervisi kunjungan kelas. Dalam program supervisi kunjungan kelas hendaknya mencerminkan tentang adanya jenis kegiatan, tujuan dan sasaran, pelaksanaan, waktu dan instrumen. Sedangkan dalam organisasi supervisi tercermin mekanisme pelaksanaan, pelaporan dan tindak lanjut. Untuk menjamin kelancaran kegiatan supervisi hendaknya supervisor berkoordinasi dengan pengelola sekolah (kepala sekolah, guru, staf tata usaha) dan Korwas.

b. Menyiapkan instrumen atau penjelasan teknis pelaksanaan supervisi kunjungan kelas dan kebijakan terbaru tentang petunjuk teknis pelaksanaan pendidikan di sekolah.

2. Pelaksanaan

Hal-hal pokok yang perlu mendapat perhatian supervisor dalam melaksanakan kegiatan supervisi di sekolah antara lain:

a. Supervisi kunjungan kelas hendaknya dilakukan berkesinambungan,

b. Supervisi hendaknya dilakukan pada awal dan akhir semester dengan maksud sebagai bahan perbandingan.

c. Supervisor hendaknya terampil dalam menggunakan perangkat instrumen

d. Mampu mengembangkan supervisi kunjungan kelas.

e. Supervisi kunjungan kelas bukanlah mencari kesatahan dan bukan pula menggurui, tetapi bersrfat pemecahan masalah mencari solusi terbaik.

f. Supervisi kunjungan kelas hendaknya mencakup segi teknis kependidikan dan teknis administrasi.

g. Supervisor hendaknya menguasai substansi materi yang disupervisi dan melengkapi diri dengan berbagai instrumen yang dibutuhkan. 
h. Karena supervisi kunjungan kelas bersifat pembinaan, maka para supervisor harus memiliki kemampuan profesi dan wawasan yang luas tentang pendidikan di sekolah.

i. Dalam peiaksanaan supervisi kunjungan keias prtnsip KISS (koordinasi, integrasi, singkronisasi dan simplikasi) hendaknya diperhatikan dengan sungguhsungguh.

Mencermati hasil analisis Program Supervisi Januari tahun 2018 di SDN Margorejo III Surabaya secara umum ditemukan beberapa kelemahan yang perlu diperbaiki bagi peningkatan profesionalisme guru, seperti: kurangnya pengunaan media pembelajaran, strategi pembelajaran yang digunakan masih konvensional dengan menggunakan metode ceramah, tidak ada variasi metode pembelajaran, tidak adanya kesesuaian antara RPP yang dibuat dengan pelaksanaan pembelajaran.

Melihat kenyataan seperti ini sebagai kepala sekolah sebagai Supevisor berkewajiban untuk membina, membimbing, dan meningkatkan profesionalisme guru melalui supervisi kunjungan kelas yang secara menyeluruh dan sistematis yang diharapkan setelah kegiatan dilakukan agar terjadi perbaikan yang signifikan dalam profesionalisme guru di SDN Margorejo III Surabaya.

Berdasarkan permasalahan diatas, maka rumusan masalah pada penelitian tindakan sekolah ini adalah "Bagaimana meningkatkan kompetensi profesional guru melalui supervisi kunjungan di SDN Margorejo III Surabaya?”
Tujuan penelitian tindakan sekolah ini adalah untuk meningkatkan profesionalisme guru melalui supervisi kunjungan kelas di SDN Margorejo III Surabaya. Hipotesis tindakan pada penelitian tindakan sekolah ini adalah supervisi kunjungan kelas dapat meningkatkan profesionalisme guru di SDN Margorejo III Surabaya.

\section{METODE}

Metode penelitian yang digunakan pada penelitian ini penelitaian tindakan sekolah. Penelitian tindakan sekolah merupakan rangkaian tindakan yang digunakan untuk memecahkan masalah yang ada di sekolah. Pelaksanaan siklus I dilaksanakan pada tanggal 13-27 September 2018 dan pelaksanaan siklus II (kedua) dilaksanakan pada 28-12 September 2018. Tempat penelitian ini di SDN Margorejo III Surabaya.

1.Siklus pertama.

a. Perencanaan. Pada tahap ini, kegiatan yang dilakukan adalah:

1) Merumuskan masalah yang akan dicari solusinya

2) Merumuskan tujuan penelitian

3) Merumuskan indikator keberhasilan penelitian

4) Merumuskan langkah-langkah kegiatan penelitian

5) Menyusun instrumen pengamatan dan evaluasi;

6) Menenentuan waktu dan tempat pelaksanaan penelitian

b. Pelaksanaan

Pada tahap ini peneliti melaksanakan rencana tindakan kegiatan supervisi dilakukan dengan kunjungan kelas. Berikut ini langkah-langkah pada tahap pelaksanaan supervisi kunjungan kelas: 
1) Supervisor masuk ke kelas dengan berdiri dengan tenang

2) Supervisor mengamati seluruh aktivitas guru dalam pembelajaran di kelas.

3) Supervisor mencatat hasil temuan guru

4) Mengakiri proses supervisi kunjungan kelas

5) Mengadakan pertemuan balikan dengan guru

6) Mengadakan tindak lanjut terhadap pelaksanaan supervisi

c. Pengamatan dan evaluasi

Dalam melakukan pengamatan terhadap profesionalisme guru di kelas, kepala sekolah mengamati seluruh aspek profesionalisme guru.

\section{d. Refleksi}

Untuk mengetahui hasil dariproses pelaksanaan tindakan yang telah dilakukan, maka dilakukan refleksi. Hasil dari refleksi akan dijadikan dasar untuk memperbaiki tindakan pada siklus selanjutnya. Setelah dilakukan refleksi.

Instrumen yag digunakan instrumen lembar observasi melihat penguasaan profesionalisme guru. Tenik pengumpulan data melalui pengamatan. Pengamatan dilakukan saat guru sedang melaksanakan pembelajaran. Studi dokumen dilaksanakan pada waktu meneliti administrasi kelas.

Analisis yang digunakan adalah Analisis data menggunakan analisis kuantitatif deskriptif. Kuantitatif deskriptif yaitu menyajikan data dalam bentuk grafik, mencari rata-rata, nilai tertinggi dan nilai terendah. Indikator Ketercapaian penelitian tindakan sekolah dalam ini untuk peningkatan profesionalisme guru adalah Rata-rata nilai pengamatan guru terhadap pelaksanaan pembelajaran adalah 75 .

\section{HASIL DAN PEMBAHASAN}

Pada siklus I (satu) terdiri dari emapat kegiatan, yaitu sebagai berikut:

1. Tahap Perencanaan

Pada tahap ini peneliti mempersiapkan pertemuan sesuai jadwal yang sudah disusun pada kunjungan kelas oleh Kepala Sekolah, perangkat pembelajaran yang terdiri dari Rencana Kegiatan, format-format penilaian, Rencana Pelaksanaan Pembelajaran yang disusun oleh guru pada sekolah yang akan dikunjungi, Buku Standar Proses dan Foto copy pembelajaran kooperatif kolaboratif.

2. Tahap Pelaksanaan Kegiatan

Sebenarnya proses kunjungan dilaksanakan untuk semua guru dan semua kelas, namun yang dijadikan obyek penelitian oleh peneliti hanya guru kelas yang langsung peneliti tangani. Peserta kelompok guru kelas terdiri dari guru-guru dari sekolah berikut:

1) Pertemuan persiapan,

2) Pengantar oleh Kepala sekolah,

3) Pembagian instrumen,

4) Pelaksanaan Pembelajaran,

5) Penilaian Rencana Pelaksanaan Pembelajaran dan pelaksanaan pembelajaran oleh Guru pengamat dan kepala sekolah,

6) Penilaian Admnistrasi Guru Kelas,

7) Mendiskusikan hasil pengamatan dan penilaian oleh guru dipimpin kepala sekolah yang sekolahnya dijadikan obyek pengamatan/penilaian. 


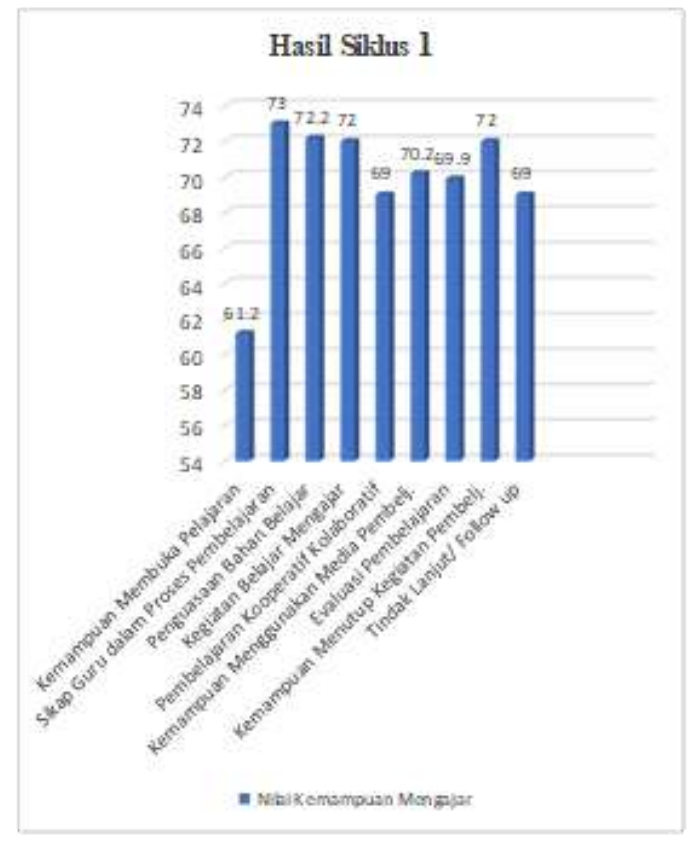

Diagram 1 Rata-rata Nlai Indikator Kemampuan Mengajar Seluruh Guru pada siklus I

Berdasarkan Diagram 1 di atas, jelas terlihat bahwa pelaksanaan pembelajaran guru dalam proses pembelajaran masih rendah. Pada aspek Indikator Kemampuan Membuka Pelajaran rata-rata penguasan guru 61,2; Indikator Sikap Guru dalam Proses Pembelajaran rata-rata penguasan guru 73; Indikator Penguasaan Bahan Belajar rata-rata penguasan guru 72,2; Indikator Kegiatan Belajar Mengajar rata-rata penguasan guru 72; . Indikator Pembelajaran Kooperatif Kolaboratif rata-rata penguasan guru 69; dan Indikator Kemampuan Menggunakan Media Pembelj rata-rata penguasan guru 70; Indikator Evaluasi Pembelajaran ratarata penguasan guru 69,9; Indikator Kemampuan Menutup Kegiatan Pembelajaran rata-rata penguasan guru 72; dan Indikator Tindak Lanjut/ Follow up rata-rata penguasan guru adalah 69 . Berikut ini merupakan nilai rata-rata kemampuan mengajar setiap guru pada siklus I bisa dilihat pada Diagram 2 di bawah ini:

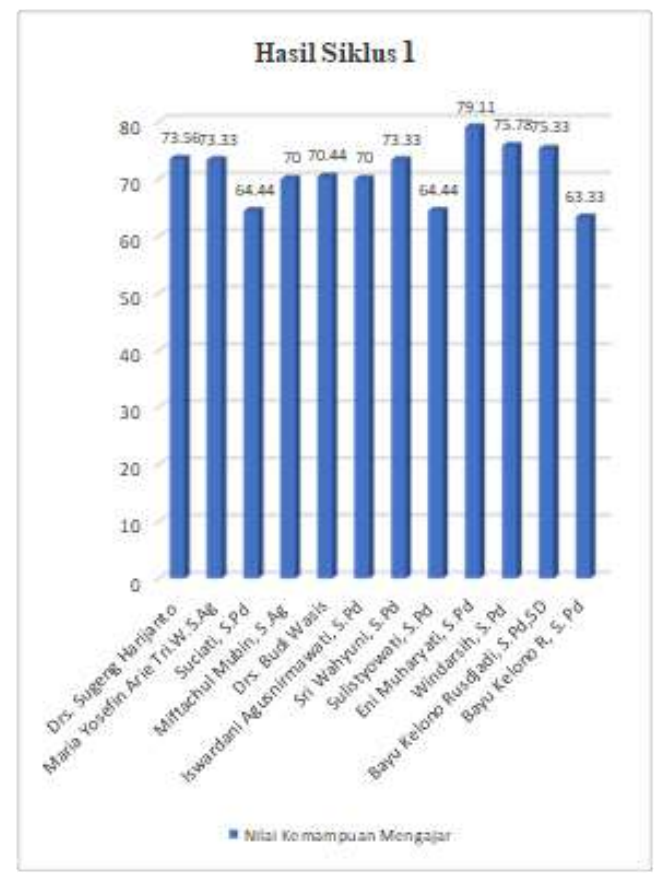

Diagram 2 Nilai Rata-Rata Kemampuan Guru Mengajar pada Siklus 1

Berdasarkan hasil siklus I (satu) pada gambar 2 diatas, nilai rata-rata kompetensi pedagogik guru di SDN Margorejo III adalah 71,09. rata-rata nilai yang terendah adalah 63,33 dan rata-rata nilai yang tertinggi adalah 79,11. Karena indikator pencapain penelitian tindakan sekolah belum tercapai, maka peneliti melanjutkan pada siklus ke II.

Pelaksanaan kegiatan Kunjungan Kelas untuk siklus II dilaksanakan sebagai berikut: Pelaksanaan teknik kunjungan kelas diatur dengan tahapan sebagai berikut: (1) Pertemuan persiapan, (2) Pengantar Oleh kepala sekolah, (3) Pembagian instrumen, (4) Pelaksanaan Pembelajaran, (5) Penilaian Rencana Pelaksanaan Pembelajaran dan pelaksanaan pembelajaran oleh Guru pengamat dan kepala sekolah, (6) Penilaian Admnistrasi Guru Kelas, (7) 
Mendiskusikan hasil pengamatan dan penilaian oleh guru dipimpin kepala sekolah yang sekolahnya dijadikan obyek pengamatan/penilaian. Berikut ini hasil nilai rata-rata indikator kemampuan mengajar guru pada siklus ke II pada Diagram 3:

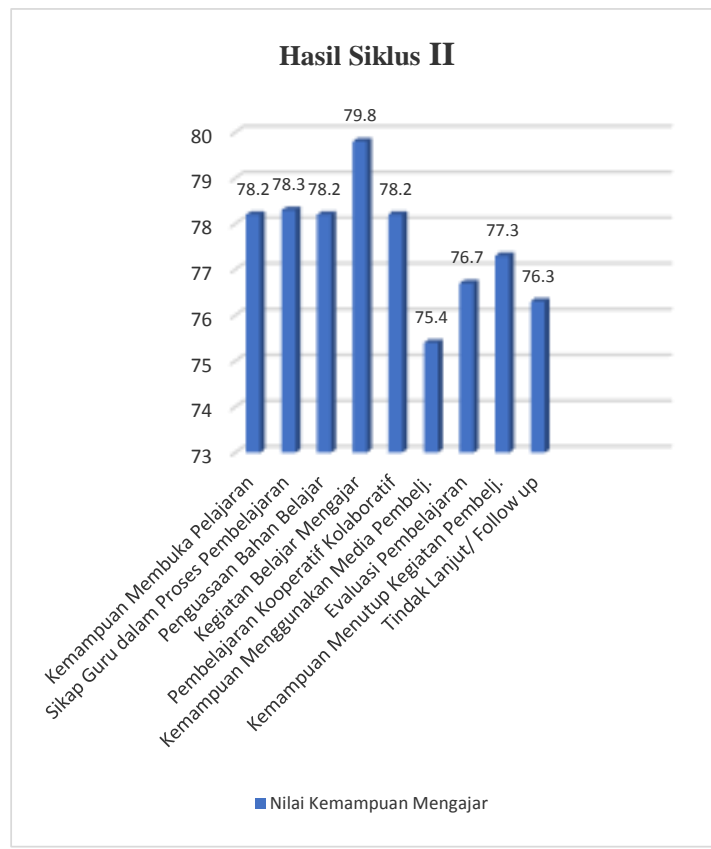

Diagram 3 Rata-rata Nlai Indikator Kemampuan Mengajar Seluruh Guru pada siklus II

Dari Diagram 3 di atas, jelas terlihat bahwa pelaksanaan pembelajaran guru dalam proses pembelajaran baik. Pada aspek Indikator Kemampuan Membuka Pelajaran rata-rata penguasan guru 78,2; Indikator Sikap Guru dalam Proses Pembelajaran rata-rata penguasan guru 78,3; Indikator Penguasaan Bahan Belajar rata-rata penguasan guru 78,2; Indikator Kegiatan Belajar Mengajar rata-rata penguasan guru 79,8;. Indikator Pembelajaran Kooperatif Kolaboratif rata-rata penguasan guru 78,2 ; dan Indikator Kemampuan Menggunakan Media Pembelj rata-rata penguasan guru 75,4; Indikator Evaluasi Pembelajaran rata-rata penguasan guru 76,7 ; Indikator
Kemampuan Menutup Kegiatan Pembelajaran rata-rata penguasan guru 77,3; dan Indikator Tindak Lanjut/ Follow up rata-rata penguasan guru adalah 76,3. Berikut ini merupakan nilai ratarata kemampuan mengajar setiap guru pada siklus I bisa dilihat pada Diagram 4 di bawah ini:

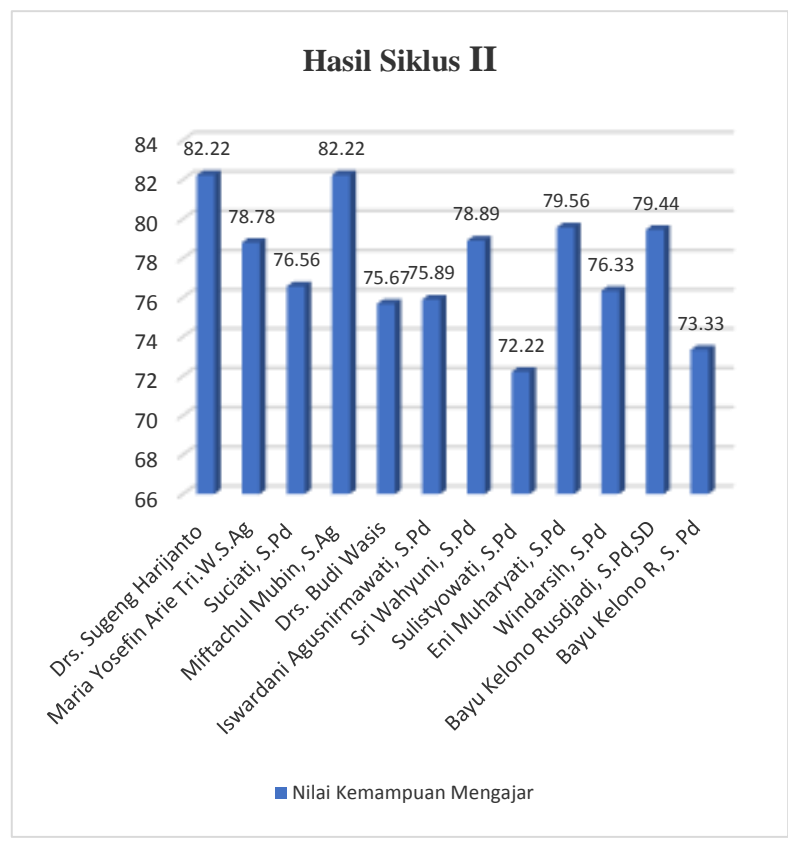

Gambar 4 Nilai Rata-Rata Kemampuan Guru Mengajar pada Siklus II

Berdasarkan hasil siklus II pada Diagram 4 diatas, nilai rata-rata kompetensi pedagogik guru di SDN Margorejo III adalah 77,6. rata-rata nilai yang terendah adalah 73,33 dan rata-rata nilai yang tertinggi adalah 82,22. Karena indikator pencapain penelitian tindakan sekolah pada siklus ke II sudah tercapai dengan nilai rata-rata diatas 75, maka penelitian tindakan sekolah berakhir pada siklus ke II.

Perilaku supervisor dalam kunjungan kelas yang baik merupakan gambaran sikap profesionalisme guru terhadap pelaksanaan tugas profesionalisasinya. Jadi perilaku supervisor dalam kunjungan keras 
sangat besar hubungannya dengan sikap profesionalisme guru dalam mengajar oleh sebab itu sebaiknya ditingkatkan perilaku supervisor dalam kunjungan kelas, karena perilaku supervisor dalam kunjungan kelas yang tinggi akan menyebabkan guru mau melakukan aktivitas kerja yang baik atau tinggi.

\section{SIMPULAN DAN SARAN}

\section{Simpulan}

Berdasarkan pembahasan diatas, dapat disimpulkan sebagai berikut:

1. Supervisi kunjungan kelas dapat meningkatkan profesionalisme guru dalam mengajar di SDN Margorejo III Surabaya Tahun Pelajaran 2017/2018. Hal tersebut dibuktikan dengan peningkatan dari siklus ke siklus. Pada siklus I nilai rata-rata kompetensi pedagogik guru di SDN Margorejo III adalah 71,09. rata-rata nilai yang terendah adalah 63,33 dan rata-rata nilai yang tertinggi adalah 79,11. Sedangkan pada siklus ke II nilai rata-rata kompetensi pedagogik guru di SDN Margorejo III adalah 77,6 . rata-rata nilai yang terendah adalah 73,33 dan rata-rata nilai yang tertinggi adalah 82,22. Indikator ketercapaian penelitian tindakan sekolah nilai rata-rata kemampan guru dalam mengajar diatas 75 melebihi target yag ditentukan peneliti.

\section{Saran}

1. Untuk meningkatkan sikap profesionalisme guru maka sikap profesionalisme guru yang mengajar pada sekolah tersebut harus diperhatikan secara lebih baik, sebab masalah yang ada pada sekolah yang sarana prasarananya kurang tentu saja tidak sama dengan masalah yang ada pada sekolah yang sarana prasaranya cukup. Oleh karena itu sangatlah wajar jika masalah tersebut perlu diperhatikan sehingga guru tersebut dapat meningkat sikap profesionalisme secara baik.

2. Di dalam guru mengajar tentu saja terdapat berbagai hal yang dapat meningkatkan sikap profesionalisme guru. Dalam kaitannya dengan masalah ini maka penulis mempunyai saran, bahwa guru yang mengajar pada sekolah yang sarana prasarananya kurang hendaknya diberikan fasilitas belajar yang sama dengan sekolah-sekolah lainnya yang sarana prasaranya cukup seperti sekolah di kota.

3. Bahwa perilaku supervisor dalam kunjungan kelas idealnya dilaksanakan sekurang-kurangnya 3 kali setiap guru dalam satu semester atau 6 kali setiap dalam setahun. Karena semakin sering dilakukan perilaku supervisor dalam kunjungan kelas terhadap guru-guru akan semakin sering guru-guru tersebut memperbaiki program persiapan, pelaksanaan, dan evaluasi dalam pengajarannya, sehingga kinerjanya akan menunnjukkan hasil kerja yang baik. 
DAFTAR RUJUKAN

Nasution, S. 2000. Didaktik Asas-asas Mengajar, Jakarta : PT Bumi Aksara

Sahertian, dkk. 1982. Teknik dan Supervisi Pendidikan, Surabaya : Usaha Ofset Printing

Abidin. 1991. Supervisi Pendidikan, Bandung : Suri

Ametembun. 1981. Supervisi Pendidikan, Penuntun Bagi Para penilik, Pengawas Sekolah, kepala Sekolah, Jakarta

Depdikbud. 1989. Undang-Undang Dasar 1945, Jakarta 1990. Perpustakaan Pemerintah RI No 28 tahun 1990 Tentang Pendidikan Dasar : Sekretariat Negara

1991. Daftar Penilaian Pelaksanaan Pegawai Negeri Sipil. Jakarta: Dekdikbud 1995. Pedoman Penulisan Karya Ilmiah dan Angka Kredit
Pengembangan Profesi Guru, Jakarta

Mujiman, H. 1991. Pokok-pokok Penulisan Ilmiah, Surabaya : Widya Bhawana

Nawawi, H. 1985. Administrasi Pendidikan, Gunung Agung

Wirawan, S. 1991. Media Indonesia, Jakarta : Gramedia

Supranto. 1981. Statistik Teori dan Aplikasi II, Jakarta : Erlangga

Hadi, S. 1986. Metodologi Research IV. Yogyakarta : Yayasan Fakultas Psikologi UGM

Vrendenbreght. 1980. Metode dan Teknik Penilitian Masyarakat, Jakarta : Gramedia

Nurkancana, W. 1983. Evaluasi pendidikan, Jakarta : Usaha Nasional

Surahmad, W.1982. Metodologi Penelitian, Bandung : Tarsito 